\title{
Effects of Effective Microorganisms on Meat Quality, Microstructure of the Longissimus Lumborum Muscle, and Electrophoretic Protein Separation in Pigs Fed on Different Diets
}

\author{
Patrycja Reszka ${ }^{1, *(\mathbb{D})}$, Dorota Cygan-Szczegielniak ${ }^{1}$, Hanna Jankowiak ${ }^{2}$, Aleksandra Cebulska ${ }^{2}$, \\ Beata Mikołajczak ${ }^{3}$ iD and Joanna Bogucka ${ }^{1}$ \\ 1 Department of Animal Physiology, Physiotherapy and Nutrition, Faculty of Animal Breeding and Biology, \\ UTP University of Science and Technology, Mazowiecka 28, 85-084 Bydgoszcz, Poland; \\ cygan@utp.edu.pl (D.C.-S.); bogucka@utp.edu.pl (J.B.) \\ 2 Department of Animal Breeding, Faculty of Animal Breeding and Biology, UTP University of Science and \\ Technology, Mazowiecka 28, 85-004 Bydgoszcz, Poland; jankowiak@utp.edu.pl (H.J.); \\ cebulska@utp.edu.pl (A.C.) \\ 3 Department of Meat Technology, Faculty of Food Science and Nutrition, Poznań University of Life Sciences, \\ Wojska Polskiego 31,60-624 Poznań, Poland; beata.mikolajczak@up.poznan.pl \\ * Correspondence: patrycja.reszka09021992@wp.pl
}

Received: 16 September 2020; Accepted: 25 September 2020; Published: 26 September 2020

Simple Summary: Pork is the most popular meat among consumers in Poland, but it can also be a source of pathogens. Therefore, there is a need to find effective prophylaxis in order to ensure that consumers have access to safe food with the desired nutritional qualities and, above all, food that is free of pathogens. In order to meet these expectations, producers use probiotics containing effective microorganisms (EMs) offered in the market. In this study the same probiotic, EM Bokashi, was used for the first time in combination with three nutritional variants with proteins of different origin.

\begin{abstract}
The aim of the study was to determine how effective microorganisms influence meat quality, the microstructure of the longissimus lumborum muscle, and electrophoretic protein separation. The study group consisted of 150 piglets divided into three feeding groups: C, E1, and E2. The feeding groups included C - a standard fodder blend with a full share of post-extracted soya meal; E1-a $50 \% / 50 \%$ mix of pea and lupine/soya bean in phase I of fattening and a $75 \% / 25 \%$ mix of pea and lupine/soya bean in phase II of fattening; and E2-a 50\%/50\% mix of pea and lupine/soya bean in phase I of fattening and in 100\% pea and lupine in phase II of fattening. The experimental factor was the addition of the EM Carbon Bokashi probiotic to the diet (C + EM, E1 + EM, E2 + EM). Influence of the feeding system on the following parameters was also estimated. After slaughter, the meat quality, $L L$ muscle microstructure, and electrophoretic protein separation were assessed. In the C + EM group, a lower water-holding capacity was demonstrated. Meat from pigs fed the effective microorganism additive was much harder in the E1+EM group compared to meat from pigs from the E1 group. A beneficial effect of effective microorganism was found in the E2 + EM group, where less thermal leakage from the meat was demonstrated. A beneficial effect of the feeding system on thermal leakage and loin eye area in the E2 + EM group was demonstrated. In the C + EM group, a lower total number of muscle fibers was demonstrated. The addition of effective microorganism caused an increase in the diameter of fast twitch fibers in the E1 + EM group. In the same group of pigs, effective microorganisms caused a lower proportion of fiber fission. This nutritional variant appears to be the most appropriate for proteins as well, because it led to the most favorable percentage of individual proteins after effective microorganisms supplementation in the longissimus lumborum muscle.
\end{abstract}


Keywords: pigs; probiotic; meat quality; muscle fibers; histopathological parameters; intramuscular fat; protein electrophoresis

\section{Introduction}

Pork is one of the most popular meat choices for consumers in worldwide [1]. Unfortunately, it is also often a potential source of pathogens that occur naturally in pigs but cause diseases due to microorganisms such as Salmonella spp., Toxoplasma gondii, Listeria monocytogenes, Campylobacter spp., and Staphylococcus aureus. In order to develop an effective prophylaxis of pathogen-free pork consumption, it is important to find appropriate methods to eliminate pathogens from meat [2]. Healthy food with appropriate dietary qualities is a priority among consumers. Therefore, in order to meet these expectations, producers use feed additives-probiotics—containing effective microorganisms (EMs), which combat pathogenic microflora and improve the microbiological balance of the digestive system and meat quality [3,4]. Many authors have shown a beneficial effect of probiotic preparations on meat quality, including succulence, elasticity, tenderness, and color [3-5]. On the other hand, intensive breeding work, aimed at achieving the highest possible production-and, thus, the highest meat content of fattening pigs-has led to histopathological changes in the muscles, such as changes in the size and shape of fibers (atrophy or hypertrophy), splitting, and fiber necrosis. The individuals in which we most frequently encounter these changes are fattening pigs of the pietrain breed and its hybrids [6]. According to the existing research, intensive selection, in addition to genetic conditions, nutrition, body weight, and breed, may also affect the number of muscle fibers [7]. The histological and biochemical properties of the muscle, e.g., the area and type of fibers or the glycolytic and oxidative properties, are the elements that determine the quality of meat $[8,9]$.

In January 2006, after a ban on antibiotics was introduced in the European Union, all dietary supplements (e.g., probiotics, prebiotics, synbiotics, and herbs) have become an object of interest for scientists and the subject of many studies in order to find an effective alternative. The term 'probiotic' refers to live microorganisms (with proven probiotic properties and origin) that, when administered in sufficient quantities, have a beneficial effect on animal health and productivity [10]. Currently, the majority of the produced probiotics use lactic acid bacteria (Lactobacillus acidophilus), which prevent the development of Salmonella, Escherichia coli, and Candida albicans and stimulate immunity. Other strains of the genus Lactobacillus synthesize vitamins D and K (L. brevis), produce the antibiotic lactolin (L. plantrum), or increase tolerance to lactose (L. rhamnosus). Other bacteria used in probiotic production, such as Bifidobacterium bifidium, inhibit the development of pathogens; Enterococcus faecium destroys rotaviruses [11]. The probiotic preparation used in this experiment contains strains of microorganisms, including Lactobacillus plantrum, Enterococcus faecium, Bacillus licheniformis, and Clostridium butyricum, which do not undergo any technological treatment [12].

In Poland, where $80 \%$ of animal nutrition is based on imported soya bean meal, it is important to find an alternative source of protein for reasons of the food safety of both humans and animals. The solution to this problem may be to use native legumes-peas and lupine [13]. Therefore, this paper presents three nutritional variants, with proteins of different origin, combined with the addition of a probiotic.

The aim of the study was to determine how effective microorganisms (EM) influence meat quality, the microstructure of the longissimus lumborum $(L L)$ muscle (the enzymatic profile of the muscle fibers, intramuscular fat content, and the occurrence of pathological changes), and the electrophoretic distribution of selected proteins in pigs fed on diets with proteins of different origin. 


\section{Materials and Methods}

\subsection{Maintenance and Feeding of Animals}

The tests were carried out at the Fatstock Pig Utility Control Station in Mełno, Poland. The study covered 150 piglets FF1 (Polish Landrace PL $\times$ Polish Large White PLW) with o'F1 (Pietrain $\times$ Duroc), $50 \%$ gilts and $50 \%$ hogs), at an initial body weight of about $30 \mathrm{~kg}$. The animals were placed into two separate, identically constructed and equipped rooms - the control room (groups C, E1, and E2) and the experimental room (groups C + EM, E1 + EM, and E2 + EM). Each animal was marked and placed in an individual $2 \mathrm{~m}^{2}$ pen with straw bedding equipped with automatic feeder and nipple drinker, allowing constant access to water (Directive No. 2010/63/EU). Wheat straw was replaced three times a week and animals' pens were augmented by metal chains.

The fattening pigs were divided into three groups: the control group $(\mathrm{C})$ and the experimental groups (E1 and E2), depending on the nutrition they were receiving. Group C was fed a standard diet based on post-extraction soya bean meal (100\%). In fattening phase I, groups E1 and E2 were given a feed mixture with $50 \%$ soya bean and 50\% pea and lupine. In fattening phase II, group E1 were fed a compound feed of $25 \%$ soya bean and $75 \%$ pea and lupine, while in group E2 soya bean protein was completely replaced with $100 \%$ pea and lupine. The composition of the feeds is shown in Table 1.

Table 1. The composition of feeds.

\begin{tabular}{|c|c|c|c|c|c|c|}
\hline \multirow{2}{*}{ Dietary Value } & \multicolumn{2}{|c|}{ Control } & \multicolumn{2}{|c|}{ E1 } & \multicolumn{2}{|c|}{ E2 } \\
\hline & $\begin{array}{c}\text { Phase I } \\
(30-70 \mathrm{~kg})\end{array}$ & $\begin{array}{c}\text { Phase II } \\
(70-115 \mathrm{~kg})\end{array}$ & $\begin{array}{c}\text { Phase I } \\
(30-70 \mathrm{~kg})\end{array}$ & $\begin{array}{c}\text { Phase II } \\
(70-115 \mathrm{~kg})\end{array}$ & $\begin{array}{c}\text { Phase I } \\
(30-70 \mathrm{~kg})\end{array}$ & $\begin{array}{c}\text { Phase II } \\
(70-115 \mathrm{~kg})\end{array}$ \\
\hline Dry matter, $\mathrm{g}$ & 877 & 875 & 877 & 875 & 877 & 875 \\
\hline Metabolic energy, MJ & 13.39 & 13.11 & 13.32 & 13.09 & 13.32 & 13.12 \\
\hline Total protein, $\mathrm{g}$ & 170 & 159 & 171 & 157 & 171 & 160 \\
\hline Fat, $g$ & 27 & 20 & 29 & 20 & 29 & 20 \\
\hline Lysine, $\mathrm{g}$ & 10.6 & 9.7 & 10.6 & 9.7 & 10.6 & 9.7 \\
\hline Calcium, $\mathrm{g}$ & 5.9 & 5.8 & 5.9 & 5.8 & 5.9 & 5.8 \\
\hline Phosphorus, $\mathrm{g}$ & 5.3 & 5.2 & 5.3 & 5.2 & 5.3 & 5.2 \\
\hline Sodium, $g$ & 1.7 & 1.7 & 1.7 & 1.7 & 1.7 & 1.7 \\
\hline Vitamin A, IU & 10.000 & 10.000 & 10.000 & 10.000 & 10.000 & 10.000 \\
\hline Vitamin D, IU & 2.200 & 2.200 & 2.200 & 2.200 & 2.200 & 2.200 \\
\hline Vitamin E, IU & 80 & 80 & 80 & 80 & 80 & 80 \\
\hline \multicolumn{7}{|l|}{$\begin{array}{l}\text { Composition of the } \\
\text { fodder, } \% \text { : }\end{array}$} \\
\hline Soy meal $46 \%$ BO & 16 & 12 & 10 & 4 & 10 & - \\
\hline Wheat $12 \%$ & 20 & 20 & 20 & 20 & 20 & 20 \\
\hline Barley 12\% & 35 & 45 & 30 & 41 & 30 & 35 \\
\hline Triticale $10 \%$ & 25.3 & 20 & 26 & 20 & 26 & 20 \\
\hline Soybean oil & 1 & 0.3 & 1.3 & 0.3 & 1.3 & 0.3 \\
\hline Lupine 37\% & - & - & 7 & 9 & 7 & 12 \\
\hline Pea 21\% & - & - & 3 & 3 & 3 & 10 \\
\hline $\begin{array}{c}\text { PORKOVITAL T PEA } \\
2.5 \%\end{array}$ & 2.5 & 2.5 & 2.5 & 2.5 & 2.5 & 2.5 \\
\hline $\begin{array}{c}\text { SELACID GG DRY } 25 \\
\text { BR }\end{array}$ & 0.2 & 0.2 & 0.2 & 0.2 & 0.2 & 0.2 \\
\hline Total & 100 & 100 & 100 & 100 & 100 & 100 \\
\hline
\end{tabular}

In order to assess the effect of the probiotic used, animals were divided into control subgroups (without the probiotic) - C, E1, and E2-and experimental subgroups (with the probiotic) - C + EM, $\mathrm{E} 1+\mathrm{EM}$, and E2 + EM (Table 2).

The laboratory assessment covered meat samples taken from 60 animals (10 randomly pigs from each group: five gilts and five hogs) which were pooled into a single study group within each feeding system because there were no significant sex-related differences in the values of the analyzed parameters (Table 2). 
Table 2. Experiment arrangements.

\begin{tabular}{|c|c|c|c|c|c|c|c|c|c|c|c|}
\hline \multicolumn{4}{|c|}{ Control Group (C) } & \multicolumn{4}{|c|}{ Experimental Group (E1) } & \multicolumn{4}{|c|}{ Experimental Group (E2) } \\
\hline \multicolumn{2}{|c|}{ C } & \multicolumn{2}{|c|}{$\mathrm{C}+\mathrm{EM}$} & \multicolumn{2}{|c|}{ E1 } & \multicolumn{2}{|c|}{$\mathrm{E} 1+\mathrm{EM}$} & \multicolumn{2}{|c|}{ E2 } & \multicolumn{2}{|c|}{$\mathrm{E} 2+\mathrm{EM}$} \\
\hline \multicolumn{2}{|c|}{$\begin{array}{c}n=25 \\
\sigma^{x} 13+12\end{array}$} & \multicolumn{2}{|c|}{$\begin{array}{c}n=25 \\
\sigma^{x} 12 \text { \& } 13\end{array}$} & \multicolumn{2}{|c|}{$\begin{array}{c}n=25 \\
\sigma^{7} 12 \text { ๆ } 13\end{array}$} & \multicolumn{2}{|c|}{$\begin{array}{c}n=25 \\
\sigma^{3} 13 \text { क } 12\end{array}$} & \multicolumn{2}{|c|}{$\begin{array}{c}n=25 \\
\sigma^{x} 13 \text { क } 12\end{array}$} & \multicolumn{2}{|c|}{$\begin{array}{c}n=25 \\
\sigma^{\pi} 12 \text { † } 13\end{array}$} \\
\hline & & & & Body & Weight a & Slaugh & $\mathrm{er}, \mathrm{kg}$ & & & & \\
\hline$\sigma^{7}$ & q & $0^{7}$ & 우 & $0^{7}$ & o & $\sigma^{2}$ & q & $\sigma^{7}$ & q & $\sigma^{7}$ & q \\
\hline 111.27 & 107.70 & 113.42 & 112.04 & 115.63 & 109.00 & 115.86 & 112.50 & 113.82 & 111.55 & 115.86 & 115.56 \\
\hline \pm 5.70 & \pm 8.45 & \pm 4.94 & \pm 3.07 & \pm 4.67 & \pm 7.29 & \pm 4.43 & \pm 4.21 & \pm 4.88 & \pm 4.57 & \pm 4.64 & \pm 4.30 \\
\hline
\end{tabular}

Group C-standard diet based on post-extraction soya bean meal (100\%); groups E1 and E2-in phase I of fattening, a feed mix with 50\% soya bean and 50\% pea and lupine was administered; group E1-in phase II of fattening a feed mix with $25 \%$ soya bean and $75 \%$ pea and lupine was administered; group E2-100\% of soya bean protein was replaced with pea and lupine; experimental groups, with the addition of a probiotic to the diets (C + EM, E1 + EM, $\mathrm{E} 2+\mathrm{EM})[14]$.

The applied probiotic EM Carbon Bokashi [14] was administered in the amount of $5 \mathrm{~kg}$ per tonne of feed (in phase I of fattening) and $3 \mathrm{~kg}$ per tonne of feed (in phase II of fattening). Animals weighing approximately $115 \mathrm{~kg}$ were slaughtered in accordance with the applicable standards and regulations (Ordinance of the Minister of Agriculture and Rural Development of 9 September 2004). An electric stunning method was applied to the pigs.

\subsection{Quality of Meat}

The acidification of muscle tissue $48 \mathrm{~h}$ after slaughter $\left(\mathrm{pH}_{48}\right)$ was determined using an Elmetron $\mathrm{CP}-401 \mathrm{pH}$ meter with a firing electrode. The equipment was calibrated using Elmetron's pH 7.0 and pH 4.0 buffers. Meat quality was assessed $48 \mathrm{~h}$ after slaughter (without repetitions) on the $L L$ muscle, which was stored at $4-6^{\circ} \mathrm{C}$. The water-holding capacity (WHC) was determined according to Grau and Hamm [15], as modified by Pohji and Ninnivaara [16]. A 300-mg sample of minced meat was weighed and placed on Whatman filter paper between two glass plates under a constant load of $2 \mathrm{~kg}$ for $5 \mathrm{~min}$. The juice infiltration area was used to calculate the percentage of loose water in the meat, assuming that $1 \mathrm{~cm}^{2}$ of infiltration corresponds to $10 \mathrm{mg}$ of water. The infiltration surface of meat juice was measured with a planimeter. WHC was reported as the mean of three trials.

The thermal leakage was determined according to the method developed by Walczak [17], without repetitions. A 20-mg meat sample was placed on a hygroscopic gauze and heated at $85^{\circ} \mathrm{C}$ for $10 \mathrm{~min}$ in a water bath. After heating and removing the gauze, the sample was cooled to $4{ }^{\circ} \mathrm{C}$ and weighed. On the basis of the weight difference before and after heat treatment, the percentage of weight loss was calculated.

The color of the meat was measured on a slice of raw meat using a Minolta CR 310 photocolorimeter (Konica Minolta, Tokyo, Japan) with a measuring hole diameter of $50 \mathrm{~mm}$. The instrument was standardised using the white calibration plate CR310 with coordinates $Y=92.80, x=0.3175$ and $y$ $=0.3333$. The color parameters of individual samples were determined in the CIE $L^{*} a^{*} b^{*}$ system ( $\mathrm{L}^{*}$ - brightness; $\mathrm{a}^{*}$-proportion of red; $\mathrm{b}^{*}$ - proportion of yellow) [18] using Illuminant D65 and a standard $2^{\circ}$ observer, without repetitions.

Marbling was determined using a slice of raw meat weighing $120 \mathrm{~g}$. The visual assessment was carried out by a team of five specialists and the results was presented as the mean of these five assessments. Marbling was assessed on the basis of Canadian and American models on a 10-degree scale $[19,20]$, where $1=$ no intramuscular fat content and $10=$ very high marbling.

The tenderness of the meat was determined using an Instron 3342 strength tester equipped with a Warner-Bratzler cap, according to the method by Szalata et al. [21]. Meat samples weighing $120 \mathrm{~g}$ were heated in a water bath to an internal temperature of $70{ }^{\circ} \mathrm{C}$. Heat treatment was conducted in a $0.85 \% \mathrm{NaCl}$ solution. Five $10 \mathrm{~mm} \times 10 \mathrm{~mm}$ rods were cut out along the muscle fibers, then cut perpendicularly to the muscle fibers. The result, which is the mean of five trials, was recorded as maximum shear force expressed in $\mathrm{N}$. 
The outline of the surface area of the $L L$ muscle (sirloin eye area) was drawn on a slice of raw meat $(120 \mathrm{~g})$ and the surface area $\left(\mathrm{cm}^{2}\right)$ was determined using the planimetric method.

\subsection{Histochemical Analysis}

To assess the microstructure of the muscle, a $5 \times 15 \mathrm{~mm}$ sample was taken from the longissimus lubmorum $(L L)$ muscle between the 4 th and 5 th ribs. Next, the samples were frozen in liquid nitrogen at $-196{ }^{\circ} \mathrm{C}$. The frozen muscle samples were transferred to cryostat (Thermo Shandon, London, UK) and cut into $10-\mu \mathrm{m}$ thick histological fragments at about $-25^{\circ} \mathrm{C}$. The fragments were then placed on a slide and subjected to the following histochemical reactions:

In order to determine the muscle fiber types, a combined reaction was carried out to the activity of two enzymes [22]: tetrazoline reductase NADH-TR (incubation of preparations in the incubation fluid: NADH, NBT, and $0.1 \mathrm{M}$ phosphate buffer at $\mathrm{pH} 7.4$ and $37^{\circ} \mathrm{C}$ for $1 \mathrm{~h}$ ) and myofibrillar ATP (pre-incubation of the preparations in an acidic solution at $\mathrm{pH} 4.0$ for $3 \mathrm{~min}$, followed by incubation in an incubation fluid: $\mathrm{ATP}, \mathrm{CaCl}_{2}$, and sodium barbiturate at $\mathrm{pH} 9.6$ and $37^{\circ} \mathrm{C}$ for $30 \mathrm{~min}$ ). The effect of the reaction is the transformation of colorless tetrazolium salts into visible formazan granules, which allows for an unambiguous determination of the metabolic/structural type of fibers: STO (slow twitch oxidative fiber, dark brown or black), FTO (fast twitch oxidative fiber, blue), and FTG (fast twitch glycolytic fiber, light, straw-colored).

In order to determine the percentage of intramuscular fat (IMF; intramuscular fat is red), the samples were dyed oil red according to Dubovitz et al. [23]. First, the slides was taken from the freezer and left to dry at room temperature for two minutes. Then, immersing the slides in various reagents with specific periods of time: formaldehyde $4 \%$ ( $5 \mathrm{~min}$ ), distilled water $(5 \mathrm{~min})$, oil red solution (Sigma-Aldrich, Poznan, PL, $15 \mathrm{~min})$, distilled water (15 min).

In order to determine pathological changes in the muscle, topographic staining with hematoxylin and eosin was performed. Pathological changes, such as giant fibers, necrotic fibers, and splitting, were determined.

Then, microscopic images were recorded on a computer disk using a Nikon Ci-L microscope equipped with a Nikon DS-Fi3 camera with a resolution of 5.9 MPix and NIS ELEMENTS software, enabling linear and planimetric measurements and digital analysis of the microscopic images. The percentage of individual muscle fiber types was calculated for an area of $1.5 \mathrm{~mm}^{2}$. The diameters of muscle fibers were measured according to the method given by Brooke [24]: measuring the shortest diameters. The density of muscle fibers was calculated based on the average number of fibers per $1.5 \mathrm{~mm}^{2}$. The total number of fibers (TNF) was calculated by multiplying the fiber density and the sirloin eye area. Intramuscular fat (IMF) was determined over an area of $3 \mathrm{~mm}^{2}$ using the function of filtering out the indicated color, which calculates the percentage of red. The software also calculated the number of normal and pathological fibers over the area of $1.5 \mathrm{~mm}^{2}$ and the percentage content of these fibers.

\subsection{Sodium Dodecyl Sulfate-Polyacrylamide Gel Electrophoresis (SDS-PAGE)}

\subsubsection{Sample Preparation}

Samples of $2 \mathrm{mg}$ of raw frozen meat were mixed with a $98-\mu \mathrm{L}$ buffer $(\mathrm{pH} 6.8 ; 8 \mathrm{M}$ urea, $2 \mathrm{M}$ thiourea, $0.05 \mathrm{M}$ Tris-HCl, $0.075 \mathrm{M}$ DTT, 3\% [ $w / v]$ SDS, 0.05\% [w/v] bromophenol blue). Each sample was heated for $3 \mathrm{~min}$ at $98^{\circ} \mathrm{C}$. The protein concentration in 10- $\mu \mathrm{L}$ samples was determined using a 2-D Quant Kit (GE Healthcare Bio-Sciences, Marlborough, MA, USA). Protein from each sample (20 $\mu \mathrm{g})$ was subjected to electrophoresis.

\subsubsection{Gel Electrophoresis}

The proteins were separated using SDS-PAGE in 15\% polyacrylamide two-phase gels [25]. The resolving gel contained 30\% (w/v) acrylamide, 75\% (v/v) glycerol, $3 \mathrm{M}$ Tris [pH 8.8 ], 10\% $(w / v)$ SDS, 
$1 \%(w / v)$ ammonium persulfate, and $16 \mu \mathrm{L}$ of TEMED. The stacking gel $(10 \%(w / v)$ acrylamide, $5 \%(v / v)$ glycerol, $0.125 \mathrm{M}$ Tris (pH 6.8), distilled water, $10 \%(w / v)$ SDS, $1 \%(w / v)$ ammonium persulfate, staining buffer, and $25 \mu \mathrm{L}$ of TEMED) was poured on the layer of resolving gel. The separation was performed with buffer (0.25 M Tris base, $1.92 \mathrm{M}$ glycine, $0.5 \%$ SDS $(w / v)$, and $10 \mathrm{mM}$ of 2-mercaptoethanol). A PageRuler Plus Protein Ladder 10-250 kDa (Thermo Fisher Scientific, Waltham, MA, USA) was used as a standard for protein molecular weight (m.w.) calibration. The gels were prepared in triplicate on $80 \times 100 \mathrm{~mm}$ plates with $0.75-\mathrm{mm}$ spacers. The separation was conducted using an SE 250 type apparatus (Hoefer Scientific Instruments Company, Holliston, MA, USA). Electrophoresis was run with a constant current of $40 \mathrm{~mA}$ per two gels. Proteins were visualized by staining with $0.05 \%$ $(w / v)$ Coomassie Brilliant Blue R-250, 50\% (v/v) methanol, and 10\% $(v / v)$ acetic acid for $0.5 \mathrm{~h}$ and then destained overnight $(10 \%(v / v)$ methanol and $4.5 \%(v / v)$ acetic acid).

\subsubsection{Image Analysis}

All images of the polyacrylamide gels were acquired using an Image Master ${ }^{\circledR}$ VDS imaging system (Pharmacia Biotech, Vienna, Austria) and analyzed using Image Master ${ }^{\circledR}$ 1D Elite v. 4.0 software. Computations were based on the assumption that the area of a single protein band accounts for a percentage ratio in relation to the area of all separated protein bands, which constitutes $100 \%$.

\subsection{Statistical Analysis}

Since some results did not meet the assumptions of a normal distribution (which was verified using the Shapiro-Wilk test) or the assumptions of homoscedasticity-required for implementing parametric tests-the non-parametric Mann-Whitney $\mathrm{U}$ test was used in order to examine the statistically significant differences between two experimental groups within one feeding system ( $C$ vs. C + EM; E1 vs. E1 + EM and E2 vs. E2 + EM) for percentage of muscle fibers FTO and FTG, total number of muscle fibers (TNF), normal fibers (\%), giant fibers (\%), fiber necrosis (\%), fiber splitting (\%), intramuscular fat content $(\%)$, $\mathrm{pH}_{48}$, WHC (\%) and for marbling score. For the remaining parameters which met the assumptions of a normal distribution and homogeneity of variance, the parametric analysis of variance (ANOVA) was applied, followed by a test for multiple comparisons, i.e., post hoc Tukey test (HSD). For the purpose of analyzing the relationships between selected parameters, Spearman's rank correlation coefficient was applied. Additionally, the Kruskal-Wallis test and the comparison of mean ranks were used to test the differences between the feeding systems ( $\mathrm{C}$ vs. E1 vs. E2 and C + EM vs. E1 + EM vs. E2 + EM). The obtained results were processed statistically using Statistica 13.1 software.

\section{Results and Discussion}

\subsection{Quality of Meat}

Table 3 presents the results of the meat quality assessment.

In control group C and experimental groups E1 and E2, no influence was demonstrated of feeding pigs effective microorganisms on the degree of the acidification of muscle tissue evaluated $48 \mathrm{~h}$ after slaughter. Previous research $[3,26]$ also did not report an effect on $\mathrm{pH}_{48}$ from feeding fattening pigs effective microorganisms. Additionally, the studies conducted by Yang et al. [26] on broilers did not show the effect of Clostridium butyricum on the ultimate $\mathrm{pH}$. In contrast, studies by Zhang et al. [9] showed an increase in $\mathrm{pH}_{24}$ meat of pigs after dietary supplementation with resveratrol—a flavonoid with antioxidant and anti-inflammatory effects-in the amount of $300 \mathrm{mg} / \mathrm{L}$ per $\mathrm{kg}$ of feed, compared to the control group $(p<0.05)$. Ultimate $\mathrm{pH}$ has a significant effect on WHC of meat. The higher ultimate $\mathrm{pH}$ might lead to the stronger WHC and the lower moisture losses [27]. In addition, the $\mathrm{pH}$ value has a significant impact on meat color and tenderness [28].

In the present study, meat from the experimental group C + EM-fed a standard diet with post-extraction soya bean meal with the addition of effective microorganisms-had lower WHC $(18.16 \%)$ than the control group $(15.57 \%)(p<0.05)$. A study by Dowarah et al. [29] reported improvement 
of WHC after supplementation with Pediococcus acidilactis FT28 $(p<0.05)$. Chang et al. [28] did not demonstrate an effect of the probiotic on WHC. High WHC values may indicate a slow and steady rate of $\mathrm{pH}$ drop during the initial hours after slaughter [30]. WHC is an important criterion for classifying meat quality, mainly from the producer's point of view, as it indicates the meat's suitability for further processing, while, from the consumer's point of view, it impacts on the culinary use of the meat [31]. The beneficial effect of effective microorganisms on thermal leakage was demonstrated in experimental group E2 + EM: it was statistically significantly lower compared to the control group $(p<0.05)$. Jukna et al. [3] found that after the addition of the probiotics Yeasture and Microbond to pig feed, an improvement in the culinary properties of the meat was found. Also, the influence of diet on thermal leakage was demonstrated. In the experimental group E1+EM thermal leakage was significantly higher, compared to group E2 + EM $(p \leq 0.05)$. Bocian et al. [32] showed no effect of feeding pigs with legumes on thermal leakage. Zmudzińska et al. [33] demonstrated that feeding pigs with diets containing legume plants and extracted rapeseed meal does not affect the pork meat quality. Other authors [34] showed that the experimental diet with an addition of $5 \%$ of raw soybean seeds affected $(p<0.05)$ meat color and also meat composition.

Table 3. Effects of effective microorganisms (EM) on meat quality in pigs fed on diets with proteins of different origin.

\begin{tabular}{|c|c|c|c|c|c|c|}
\hline \multirow{2}{*}{ Traits } & \multicolumn{2}{|c|}{$\mathrm{C}$} & \multicolumn{2}{|c|}{ E1 } & \multicolumn{2}{|c|}{ E2 } \\
\hline & $\mathrm{C}$ & $\mathrm{C}+\mathrm{EM}$ & E1 & $\mathrm{E} 1+\mathrm{EM}$ & E2 & $\mathrm{E} 2+\mathrm{EM}$ \\
\hline $\mathrm{pH}_{48}$ & $5.14 \pm 0.12$ & $5.09 \pm 0.09$ & $5.13 \pm 0.06$ & $5.19 \pm 0.10$ & $5.11 \pm 0.05$ & $5.13 \pm 0.07$ \\
\hline WHC, loose water $\%$ & $\begin{array}{c}15.57^{\mathrm{a}} \pm 2.49 \\
p=0.016\end{array}$ & $\begin{array}{c}18.16^{\mathrm{b}} \pm 2.50 \\
p=0.016\end{array}$ & $17.77 \pm 2.13$ & $17.01 \pm 1.70$ & $18.89 \pm 3.72$ & $16.28 \pm 1.88$ \\
\hline Thermal leakage, \% & $24.39 \pm 1.50$ & $24.25 \pm 2.54$ & $24.44 \pm 0.63$ & $24.80 * \pm 1.96$ & $\begin{array}{c}24.80^{\mathrm{a}} \pm 2.50 \\
p=0.024\end{array}$ & $\begin{array}{c}22.38^{b *} \pm 1.25 \\
p=0.024\end{array}$ \\
\hline $\mathrm{L}^{*}$-Lightness & $56.30 \pm 1.92$ & $57.59 \pm 3.48$ & $56.49 \pm 2.36$ & $55.65 \pm 2.55$ & $56.13 \pm 1.15$ & $56.39 \pm 2.52$ \\
\hline$a^{*}$-Redness & $13.91 \pm 0.66$ & $14.13 \pm 0.86$ & $13.99 \pm 1.04$ & $14.41 \pm 0.56$ & $14.21 \pm 0.78$ & $14.00 \pm 0.98$ \\
\hline$b$ *-Yelowness & $4.50 \pm 0.64$ & $4.25 \pm 0.77$ & $4.27 \pm 0.96$ & $4.51 \pm 0.80$ & $4.89 \pm 0.55$ & $4.56 \pm 0.91$ \\
\hline Marbling, score & $1.87 \pm 0.79$ & $1.47 \pm 0.50$ & $1.59 \pm 0.49$ & $1.70 \pm 0.60$ & $1.39 \pm 0.48$ & $1.55 \pm 0.51$ \\
\hline Tenderness, $\mathrm{N}$ & $47.94 \pm 2.80$ & $46.83^{*} \pm 5.74$ & $\begin{array}{c}47.27^{\mathrm{a}} \pm 7.62 \\
p=0.030\end{array}$ & $\begin{array}{c}56.27^{\mathrm{b} *} \pm 7.28 \\
p=0.030\end{array}$ & $53.57 \pm 5.78$ & $51.34^{*} \pm 5.03$ \\
\hline Loin eye area, $\mathrm{cm}^{2}$ & $53.10 \pm 5.67$ & $55.76 \pm 6.15$ & $53.41 \pm 4.45$ & $52.62 * \pm 2.21$ & $57.59 \pm 4.96$ & $57.93 * \pm 3.31$ \\
\hline
\end{tabular}

Group C-standard diet based on post-extraction soya bean meal (100\%); groups E1 and E2-in phase I of fattening, a feed mix with $50 \%$ soya bean and $50 \%$ pea and lupine was administered; group E1-in phase II of fattening a feed mix with $25 \%$ soya bean and $75 \%$ pea and lupine was administered; group E2-100\% of soya bean protein was replaced with pea and lupine; experimental groups with the addition of a probiotic to diets $(C+E M, E 1+E M$, and E2 + EM); ${ }^{a}, \mathrm{~b}$ statistically significant differences between two experimental groups within specific nutritional systems at $p \leq 0.05 ;{ }^{*}$ statistically significant differences between the feeding systems (C vs. E1vs. E2 and $C+E M$ vs. $\mathrm{E} 1+\mathrm{EM}$ vs. $\mathrm{E} 2+\mathrm{EM})$ at $p \leq 0.05 ; p$-value for groups that differ statistically significantly within one feeding system.

The application of the Bokashi preparation did not have a significant statistical effect on the change of meat color $\left(\mathrm{L}^{*} \mathrm{a}^{*} \mathrm{~b}^{*}\right)$ in the study groups. A study by Balasubramanian et al. [35] also showed no effect of the addition of the probiotic on meat color $\left(\mathrm{L}^{*}: 58.42 ; \mathrm{a}^{*}: 17.47 ; \mathrm{b}^{*}: 6.10\right.$ at a supplementation of $0.1 \mathrm{MSP} \mathrm{g} / \mathrm{kg}$ ). Other authors, on the other hand, noted a much higher proportion of yellow among the group of pigs fed the probiotic ( 8.98 vs. 9.48; $p<0.05)$ [18]. Meng et al. [5] demonstrated the beneficial effect of supplementing the diet of fattening pigs with Bacillus subtilis and Clostridium butyricum on the proportion of yellow $(p<0.01)$ and brightness $(p<0.05)$.

The use of the Bokashi preparation did not have a significant statistical effect on meat marbling. This is consistent with the results from Balasubramanian et al. [35], but different from Meng et al. [5]. Marbling is defined as the amount and spatial distribution of visible, white fat spots present in meat. The proper degree of marbling has a beneficial effect on the succulence, tenderness, and palatability of the meat [19].

Another feature analyzed was tenderness, which depends on the age and species of the pig, as well as on the procedures before and after slaughter, among other things. The degree of tenderness is influenced by the time and conditions in which the meat matures and the proteolytic activity during 
storage [36]. In the experimental group E1 + EM (50\% soya bean and 50\% pea and lupine in phase I of fattening, 25\% soya bean and $75 \%$ pea and lupine in phase II of fattening), the differences in terms of tenderness were statistically significant. The meat from pigs fed effective microorganisms was significantly harder $(56.27 \mathrm{~N})$ than the meat from the E1 control group $(47.47 \mathrm{~N} ; p<0.05)$. On the other hand, an experiment by Yang et al. [27] found reduced cutting force in poultry, which indicates improved tenderness. However, Chang et al. [28] and Liu et al. [37] did not demonstrate a significant effect of probiotic use on meat tenderness. The influence of diet on meat tenderness was also demonstrated, which differed statistically significantly between the experimental groups $(C+E M$, $\mathrm{E} 1+\mathrm{EM}$ and $\mathrm{E} 2+\mathrm{EM})(p \leq 0.05)$. The most desirable, tender meat was obtained from pigs from the $\mathrm{C}$ + EM group, while the hardest was obtained from pigs from the E1 + EM group. In the studies by Bocian et al. [32] showed no effect of feeding pigs with legumes on meat tenderness. No effect of pig feeding with Bokashi preparation on the sirloin eye area was demonstrated in this study. Study by Balasubramanian et al. [38] also reported no effect of supplementation of the probiotic preparation Bacillus spp. at the levels of $0.01 \%$ and $0.02 \%$ on the sirloin eye area $\left(68.67\right.$ and $69.47 \mathrm{~cm}^{2}$, respectively). However, the influence of the feeding system on this feature was noted. Significantly larger sirloin eye area was demonstrated in pigs in the E2 + EM group, compared to E1 + EM ( $p \leq 0.05)$. The effect of probiotics may vary, as it depends on the type of bacteria used, the level and time of supplementation, the composition of the diet, and interactions with other dietary supplements [5].

\subsection{Microstructure of the Longissimus Lumborum Muscle}

This is one of the few studies that deals with the influence of effective microorganisms on the microstructure of the $L L$ muscle in pigs. The microstructure of the $L L$ muscle and the proportion of pathological lesions is presented in Table 4.

Table 4. Effects of effective microorganisms (EM) on the microstructure of longissimus lumborum muscle in pigs fed on diets with proteins of different origin.

\begin{tabular}{|c|c|c|c|c|c|c|c|}
\hline \multirow{2}{*}{ Traits } & & \multicolumn{2}{|c|}{$\mathrm{C}$} & \multicolumn{2}{|c|}{ E1 } & \multicolumn{2}{|c|}{ E2 } \\
\hline & & $\mathrm{C}$ & $\mathrm{C}+\mathrm{EM}$ & E1 & $\mathrm{E} 1+\mathrm{EM}$ & E2 & $\mathrm{E} 2+\mathrm{EM}$ \\
\hline \multirow{4}{*}{$\begin{array}{l}\text { Percentage of muscle } \\
\text { fibers, } \%\end{array}$} & STO & $13.60 \pm 2.50$ & $16.33 \pm 6.60$ & $14.36 \pm 4.68$ & $14.51 \pm 3.60$ & $16.10 \pm 4.41$ & $15.41 \pm 4.77$ \\
\hline & FTO & $13.69 \pm 2.82$ & $13.52 \pm 3.57$ & $13.80 \pm 2.40$ & $14.05 \pm 3.27$ & $14.70 \pm 3.76$ & $15.13 \pm 2.20$ \\
\hline & FTG & $72.71 \pm 3.21$ & $70.15 \pm 9.25$ & $71.84 \pm 6.35$ & $71.44 \pm 3.49$ & $69.20 \pm 16.14$ & $69.46 \pm 20.62$ \\
\hline & STO & $35.03 \pm 4.34$ & $35.86 \pm 4.69$ & $38.86 \pm 5.61$ & $40.82 \pm 5.21$ & $37.11 \pm 3.38$ & $39.53 \pm 2.65$ \\
\hline \multirow[t]{3}{*}{ Fiber diameter, $\mu \mathrm{m}$} & FTO & $35.44 \pm 6.52$ & $40.66 \pm 6.63$ & $\begin{array}{c}35.78^{\mathrm{a}} \pm 3.88 \\
p=0.003\end{array}$ & $\begin{array}{c}43.17^{\mathrm{b}} \pm 3.51 \\
p=0.003\end{array}$ & $\begin{array}{c}37.24^{\mathrm{a}} \pm 5.46 \\
p=0.028\end{array}$ & $\begin{array}{c}39.42^{b} \pm 2.26 \\
p=0.028\end{array}$ \\
\hline & FTG & $47.14 \pm 4.50$ & $52.30 \pm 8.71$ & $\begin{array}{c}44.68^{\mathrm{a} *} \pm 5.16 \\
p=0.012\end{array}$ & $\begin{array}{c}50.57^{\mathrm{b}} \pm 3.46 \\
p=0.012\end{array}$ & $51.26^{*} \pm 2.63$ & $52.27 \pm 3.26$ \\
\hline & Sum & $244 \pm 48$ & $228 \pm 67$ & $243 \pm 60$ & $205 \pm 22$ & $222 \pm 20$ & $232 \pm 23$ \\
\hline \multirow{3}{*}{$\begin{array}{l}\text { Muscle fiber density } \\
\text { (fiber number/1,5 } \mathrm{mm}^{2} \text { ) }\end{array}$} & STO & $35 \pm 10$ & $34 \pm 9$ & $33 \pm 7$ & $30 \pm 8$ & $34 \pm 10$ & $28 \pm 10$ \\
\hline & FTO & $34 \pm 10$ & $31 \pm 11$ & $33 \pm 7$ & $29 \pm 7$ & $27 \pm 8$ & $31 \pm 7$ \\
\hline & FTG & $175 \pm 34$ & $163 \pm 65$ & $177 \pm 52$ & $146 \pm 16$ & $161 \pm 13$ & $173 \pm 21$ \\
\hline \multicolumn{2}{|c|}{$\begin{array}{l}\text { Total number of muscle fibers } \\
\qquad(\times 1000)(\mathrm{TNF})\end{array}$} & $\begin{array}{c}744^{\mathrm{a}} \pm 368 \\
p=0.044\end{array}$ & $\begin{array}{c}694^{\mathrm{b}} \pm 488 \\
p=0.044\end{array}$ & $743 \pm 371$ & $617 \pm 254$ & $660 \pm 406$ & $652 \pm 439$ \\
\hline \multicolumn{2}{|c|}{$\begin{array}{l}\text { Intramuscular fat content, } \\
\text { (histochemically) \% }\end{array}$} & $1.66 \pm 1.55$ & $2.27 \pm 1.13$ & $1.84 \pm 1.21$ & $1.67 \pm 0.96$ & $1.66 \pm 2.05$ & $2.45 \pm 1.79$ \\
\hline \multirow{2}{*}{\multicolumn{2}{|c|}{$\begin{array}{l}\text { Normal fibers, } \% \\
\text { Giant fibers, \% }\end{array}$}} & $97.22 \pm 2.02$ & $97.36 \pm 1.97$ & $95.95 \pm 2.72$ & $98.27 \pm 1.02$ & $96.72 \pm 1.71$ & $96.60 \pm 1.86$ \\
\hline & & $1.99 \pm 1.84$ & $1.29 \pm 1.29$ & $1.76 \pm 1.80$ & $1.10 \pm 1.17$ & $1.87 \pm 1.16$ & $1.95 \pm 1.50$ \\
\hline \multicolumn{2}{|l|}{ Fiber necrosis, $\%$} & $0.11 \pm 0.18$ & $0.34 \pm 0.53$ & $0.84 \pm 3.03$ & $0.80 \pm 0.77$ & $0.60 \pm 0.82$ & $0.30 \pm 0.46$ \\
\hline \multicolumn{2}{|l|}{ Fiber splitting, \% } & $\begin{array}{c}0.68^{\mathrm{a} *} \pm 0.25 \\
p=0.041\end{array}$ & $\begin{array}{c}1.01^{\mathrm{b}} \pm 0.92 \\
p=0.041\end{array}$ & $\begin{array}{c}1.45^{\mathrm{a} *} \pm 1.1 \\
p=0.024\end{array}$ & $\begin{array}{c}0.83^{\mathrm{b}} \pm 0.81 \\
p=0.024\end{array}$ & $\begin{array}{c}0.81^{\mathrm{a} *} \pm 0.77 \\
p=0.040\end{array}$ & $\begin{array}{c}1.15^{\mathrm{b}} \pm 0.82 \\
p=0.040\end{array}$ \\
\hline
\end{tabular}

Group C-standard diet based on post-extraction soya bean meal (100\%); groups E1 and E2-in phase I of fattening, a feed mix with $50 \%$ soya bean and $50 \%$ pea and lupine was administered; group E1-in phase II of fattening a feed mix with $25 \%$ soya bean and $75 \%$ pea and lupine was administered; group E2-100\% of soy bean protein was replaced with pea and lupine; experimental groups with the addition of a probiotic to diets (C + EM, E1 + EM, E2 + EM); STO-slow twitch oxidative fibers; FTO—fast twitch oxidative fibers, FTG—fast twitch glycolytic fibers; TNF-total number fibers; ${ }^{a}$ b statistically significant differences between two experimental groups within specific nutritional systems at $p \leq 0.05$; * statistically significant differences between the feeding systems (C vs. E1 vs. E2 and $\mathrm{C}+\mathrm{EM}$ vs. E1 + EM vs. E2 + EM) at $p \leq 0.05$; p-value for groups that differ statistically significantly within one feeding system 
The proportions of different types of muscle fibers are one of the most important factors that influence the quality of meat and depend on the nutrition, breed, sex, age, and physical activity of the animal $[7,39]$. The study did not find any influence of effective microorganisms on the proportions of particular muscle fiber types (Figure 1A) and their density. Such an influence was demonstrated, however, by Lebedová et al. [40], who divided the animals into three groups: AL—ad libitum nutrition, R1-feed limitation, and R2-strong feed limitation. The mix from the AL group had a significantly lower proportion of FTG fibers $(81.38 \%$ ) compared to pigs from Groups R1 and R2 (84.03 and 84.18\%, respectively; $p<0.05$ ). Research by Brzobohaty et al. [41] carried out on hybrids of the $\mathrm{D} \times$ genotype $\left(\mathrm{LW}_{\mathrm{D}} \times \mathrm{L}\right)$ also found a significant effect of nutrition on the proportions of muscle fibers $(p<0.001)$. Pigs fed the highest level of rapeseed meal recorded the highest percentage of STO fibers (16\%) and fiber density per $\mathrm{mm}^{2}(31)$. The group of animals receiving the lowest level of crude protein $(142,82 \mathrm{~g}$ vs. 146,93 vs. $153,69 \mathrm{~g}$ ) was characterised by the highest percentage of FTG fibers $(86 \%)$, while the density of fibers was $22 / \mathrm{mm}^{2}$ [41]. The addition of resveratrolto the diet of fattening pigs at 300 and $600 \mathrm{mg} / \mathrm{kg}$ resulted in a change to more oxidative muscle fibers [9]. In this study a tendency towards fewer fibers per unit of muscle area and significant difference in TNF $(p<0.05)$ was observed in experimental groups $\mathrm{C}+\mathrm{EM}$, which affects the tender/fine structure of meat. In experiment was found a significantly larger diameter of FTO and FTG fibers in only the experimental group E1 with addition of effective microorganisms $(p<0.05)$. Of the muscle fiber types studied, the largest diameters were recorded for FTG fibers. Research by Zhou et al. [42] showed that the dietary supplementation of fattening pigs with $0.08 \%$ polyphenolic extract of Eucommia ulmoides Oliver (PEE) leaves resulted in a decrease in fiber diameter with increased fiber density $(p<0.05)$. A study by Muqader [43] reported larger diameters of muscle fibers in broiler chickens whose diet was supplemented with zinc. Similarly, a study by Zhou et al. [44] carried out on the thoracic and femoral muscles showed that the addition of $200 \mathrm{mg} / \mathrm{kg}$ and $400 \mathrm{mg} / \mathrm{kg}$ of probiotics (Bacillus subtilis, Bacillus licheniformis, and Bacillus natto) to the diet of broilers had a significant effect on the growth of muscle mass and the diameter of muscle fibers at a late stage of growth. Jin et al. [45], in their study on the thoracic and femoral muscles, found a reduction in the diameter of muscle fibers $(p<0.05)$ after the addition of $0.3 \mathrm{mg} / \mathrm{kg}$ of selenium yeast and $5 \mathrm{mg} / \mathrm{kg}$ of boron to the diet of chickens. After adding the a synbiotic consisting of $0.8 \%$ RFO prebiotic and $1 \%$ Lavipan ${ }^{\circledR}$ probiotic for Ross 308 chicken feed, Bogucka et al. [46] also observed a tendency of reduced-diameter muscle fibers. This resulted in an increase in fiber density-the fineness of the meat-which had a beneficial effect on meat quality. Moreover, the influence of different diet on the diameter of FTG fibers was also demonstrated. They were significantly larger in the E2 group, in which the diet was based only on pea and lupine (100\% in the II phase of fattening), compared to E1 group (respectively: 51.26 vs. $44,68 \mu \mathrm{m})(p<0.05)$. Bogucka et al. [47] demonstrated the impact of different nutritional strategies on the histochemical characteristics of pig muscles. The authors was found that pigs receiving less protein and energy in their diet were characterized by a higher proportion and increased diameter of FTG fibers. A higher percentage of FTG fibers with limited nutrition was confirmed by Skiba et al. [48] and Brzobohaty et al. [49].

None of the pig feeding groups studied displayed an effect from the EMs on intramuscular fat content, which was at a balanced, relatively low level: from $1.66 \%$ in the C and E2 groups to $2.45 \%$ in the E2 + EM group (Figure 1B). The reason for this may be the selection of pigs towards high meatiness at the expense of lower fat content, and thus, poorer meat quality-including succulence, palatability, and tenderness [8]. Replacing the genetically modified soya bean meal with Albatros peas had a significant impact on reducing the IMF content (from $2.18 \%$ and $2.19 \%$ to $2.04 \%$ ) in the longissimus dorsi muscle of pigs $(p<0.05)$ [50]. A study by Madera et al. [51] did not demonstrate that diet can have a significant effect on IMF content for either the protein-reduced diet or the control group. Although the authors showed a slight increase in IMF content (from 1.78\% to $2.06 \%$ ) in Alentejana purebred pigs, this is still a small amount. This was clearly confirmed by studies by Lopez et al. [52], who reported a significantly higher intramuscular fat content with a $5 \%$ reduction in protein levels in 
the diet $(p<0.003)$. According to research by Olivares et al. [53], the addition of high levels of vitamin A (dVitA; 100,000 IU) to the diet of Duroc boars resulted in a $20 \%$ increase in the IMF of their offspring.

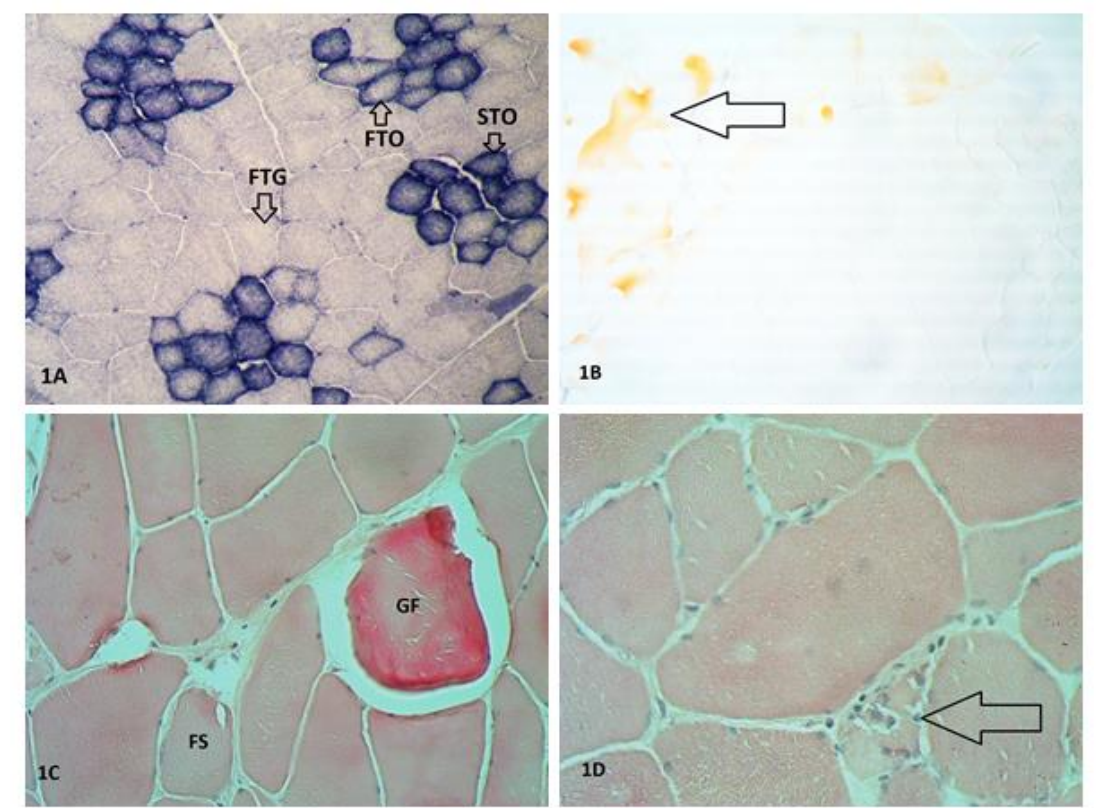

Figure 1. (A) muscle fiber types (group E1 + EM), NADH-TR tetrazolium reductase activity and myofibrillar ATP-ase activity stain, magnification $\times 125$; (B) intramuscular fat (arrow) (group E2), red oil stain, magnification 125x; (C) giant fiber (GF) and fiber splitting (FS) (E1), haematoxylin and eosin (H\&E) stain, magnification 250x; (D) fiber necrosis (group C + EM) (arrow) (C + EM), H\&E stain, magnification $400 \times$.

This study did not find any influence of an EM Bokashi preparation on the proportion of properly built muscle cells or the occurrence of giant fibers and necrosis. Normal fibers were found in $95.95 \%$ of cases in the E1 group and in $98.27 \%$ in the E1 + EM group, which is consistent with the results from other researchers [47]. The most frequently observed pathological changes included giant fibers (Figure 1C) (from 1.10\% in the E1 + EM group to 1.99\% in the C group), which can be formed from any type of muscle fiber (STO, FTO, or FTG). According to Wojtysiak [54], their occurrence is dependent on nutrition, the handling of animals before slaughter, genetic conditions, and the breed-especially those with a high susceptibility to stress. The presence of giant fibers has a significant impact on the acidity and texture parameters of meat [54]. According to Górska and Wojtysiak [55], PSE turkey meat contributes to a significant increase in the occurrence of giant fibers in muscle tissue.

Degenerative changes causing the breakdown of muscle fibers (necrosis) are indicated by the appearance of histiocytes, lymphocytes, and macrophages (Figure 1D) [56]. In terms of fiber splitting, the results were inconclusive. Fiber splitting is one of the pathological changes caused by excessive cell overload. It is usually related to coarse fibers and results from hypoxia and low metabolite uptake [57]. The adverse effects of using effective microorganisms were observed in the C + EM control and E2 + EM experimental groups, where splitting was significantly higher $(0.68 \%$ vs. $1.01 \%$ and $0.81 \%$ vs. $1.15 \%$, respectively; $p<0.05$ ) than in the control groups (Figure $1 C$ ). Differing, favourable results were reported in the experimental E1 group. Pigs from this group, fed with the addition of effective microorganisms, were characterized by a significantly lower percentage of fiber splitting (1.45\% vs. $0.83 \% ; p<0.05)$. This is confirmed by previous research by Bogucka et al. [47], who also showed a significant beneficial effect adding a synbiotic to chickens' diet had on the percentage of split fibers. Despite the inconclusive results of Semenova et al. [58], they recommend the use of feed additives (selenium, vitamin E, flavonoids, etc.) in order to reduce the occurrence of pathological changes, which appears to be decisively linked with the quality of meat. 


\subsection{Percentage of Selected Muscle Fiber Proteins in Longissimus Lumborum Muscle}

Table 5 shows the percentage of selected proteins in the $L L$ muscle of pigs depending on the nutritional variant used.

Table 5. Percentage of muscle proteins in longissimus lumborum obtained through electrophoretic separation on polyacrylamide gels with SDS (SDS-PAGE).

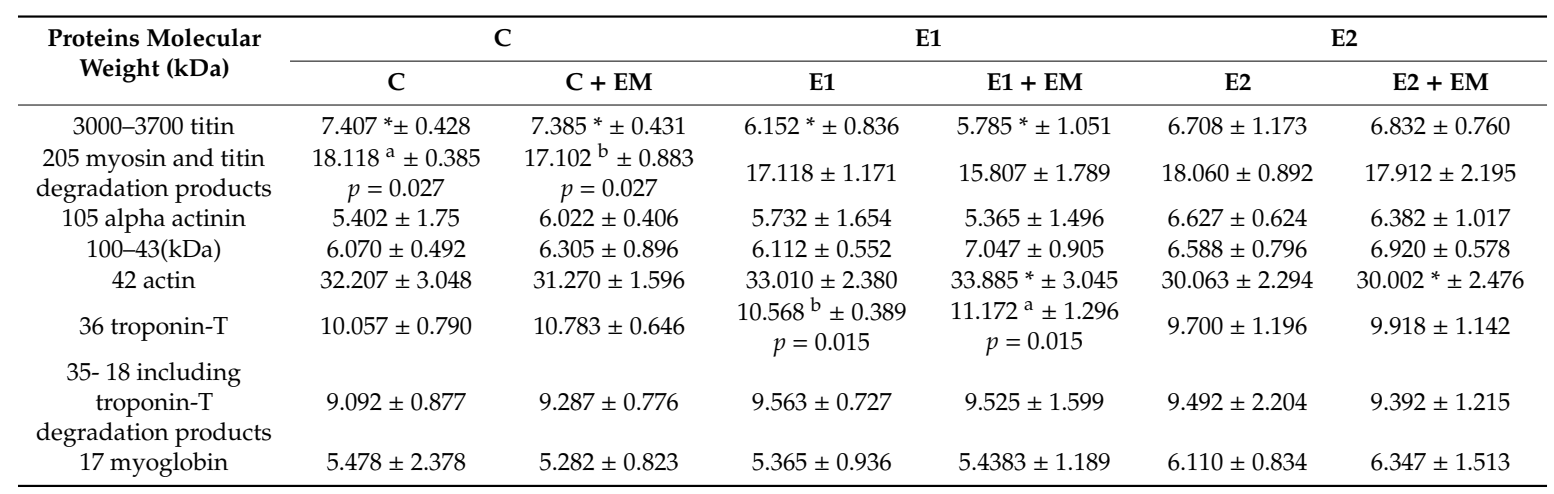

Group C-standard diet based on post-extraction soya bean meal (100\%); groups E1 and E2-in phase I of fattening, a feed mix with $50 \%$ soya bean and $50 \%$ pea and lupine was administered; group E1-in phase II of fattening a feed mix with $25 \%$ soya bean and $75 \%$ pea and lupine was administered; group E2-100\% of soya bean protein was replaced with pea and lupine; experimental groups fed an additional probiotic in the diets (C + EM, E1 + EM, E2 + $\mathrm{EM} ;{ }^{\mathrm{a}}, \mathrm{b}$ statistically significant differences between two experimental groups within specific nutritional systems at $p \leq 0.05$; * statistically significant differences between the feeding systems (C vs. E1vs. E2 and C + EM vs. E1 + EM vs. E2 $+\mathrm{EM})$ at $p \leq 0.05 ; p$-value for groups that differ statistically significantly within one feeding system.

Additionally, the elecrophoreogram (Figure 2) shows six analyzed protein bands and two ranges in relation to the molecular weight of the standard used. The highest percentage, i.e., from $30 \%$ to $33.88 \%$, was characteristic of proteins with a molecular weight of $42 \mathrm{kDa}$, while the lowest was for proteins with molecular weights of 17 and $105 \mathrm{kDa}$. Only in the case of proteins in the 3000-3700 kDa range and for the $42 \mathrm{kDa}$ protein, a different feeding system turned out to be a factor determining their quantity. For most proteins, no statistically significant influence of EMs on the percentage of them in the muscle was noted (Table 5). The exceptions were proteins weighing $205 \mathrm{kDa}(p<0.05)$, which showed a significantly higher proportion in the $C$ group compared to $C+E M$, and proteins with a weight of $36 \mathrm{kDa}(p<0.05)$ between the E1 control group and the $\mathrm{E} 1+\mathrm{EM}$ experimental group. Results similar to those presented in the study, indicating an influence of supplementation on $L L$ muscle protein changes in a lamb diet, were obtained by Malva et al. [59]: based on the protein profile, a decrease in myosin (MHC) after supplementation with quinoa and linseed was observed in their study, as well as a decrease in Tn-T with linseed supplementation. However, Adeyemi et al. [60] did not find any significant changes in the electrophoretic sections of goat meat using rapeseed and palm oil. The changes in the $205 \mathrm{kDa}$ band suggest that supplementation may affect post-mortem degradation processes and may change the integrity of the actomyosin complex. On the other hand, a decrease in this protein type may indicate oxidation processes that may induce conformational and functional modifications of muscle proteins, including the activity of the calpain system, which are enzymes particularly susceptible to oxidation [61,62].

Due to the nature of the experiment conducted, the description of electrophoretic tests also includes statistically significant correlations between the percentage of proteins and the properties of meat quality and microstructure. The most statistically significant relationships (both positive and negative) were recorded between proteins and percentage fat content and percentage of FTO fibers (IIA), as well as some meat quality properties, such as color, $\mathrm{pH}_{48}$, tenderness, and sirloin eye area. Such an interaction between characteristics results from intensive/multiplane chemical processes occurring in muscle tissue, which are often a consequence of these relationships. In relation to the proportion of FTO fibers, positive, statistically significant correlations $(p<0.05)$ were observed for proteins with molecular weights in the range of $100-43 \mathrm{kDa}(\mathrm{r}=0.557), 36 \mathrm{kDa}(\mathrm{r}=0.803)$, and $35-17 \mathrm{kDa}$ 
$(\mathrm{r}=0.574)$, which could be closely related to the aerobic and glycolytic properties of these fibers and their structure [63]. However, for the band with a weight of $17 \mathrm{kDa}$-indicated as myoglobin-the analysis of linear correlation showed a highly significant negative correlation with the percentage of FTO fibers $(\mathrm{r}=-0.73 ; p<0.05)$. FTO fibers contain less myoglobin than STO fibers, which may explain this correlation. Even less of this protein is contained in FTG fibers, but in this case, despite an inversely proportional relationship between the characteristics under consideration, it was statistically insignificant. Muscles composed mainly of type II fast fibers are more susceptible to early post-mortem proteolytic degradation than muscles composed mainly of type I slow fibers [63]. A higher proportion of muscle fibers with a predominant glycolytic metabolism, as obtained in own research, certainly leads to higher levels of glycolytic enzymes. The increased release of myofibrillar proteins in meat into the soluble fraction may indicate more intense proteolysis [64]. The above information is very useful for explaining the relationship between the various parameters obtained in our own research. It is the tenderness, color, taste, and water absorption of the meat that are determined by the proteolytic processes taking place in the muscle tissue after slaughter (post mortem) and during meat storage. The proteolytic degradation of myofibrillar and cytoskeletal proteins plays an important role in determining meat tenderness, indicating structural changes in skeletal muscles [65]. In our own research, it is worth noting a negative, statistically significant correlation $(\mathrm{r}=-0.634 ; p<0.05)$ between meat tenderness expressed in cutting force $\left(\mathrm{N} / \mathrm{cm}^{2}\right)$ and proteins with a molecular mass between 35 and $18 \mathrm{kDa}$-corresponding to troponin-T degradation products, among others. Moreover, it is worth noting obtained in own research the relationship between the number and percentage of FTO fibers and proteins with a molecular mass of $105 \mathrm{kDa}$, whose weight corresponds to alpha-actinin $(\mathrm{r}=-0.620$ and $\mathrm{r}=-0.789$, respectively; $p<0.05$ ). A higher percentage of type II fibers with a simultaneously lower concentration of proteins with a weight of $105 \mathrm{kDa}$ which has been demonstrated in own research and less of the other important degradation products of myofibrillar and cytoskeletal proteins may indicate a less intense meat tenderization process [64,65]. As shown by Grześ et al. [65] the meat tenderization process of the longissimus muscle in pigs involves the degradation or release of muscle tissue proteins, in particular those with masses of 3700,105 , and $38 \mathrm{kDa}$, and a change in the proportion of centrifugal leakage fraction proteins in the $3700-2400 \mathrm{kDa}$ and $38-36 \mathrm{kDa}$ ranges. Troponin T and its degradation products appearing during storage are an indicator of the meat maturation and tenderization process. As a result of the degradation, the structure of the sarcomere is weakened, which may lead to better tenderness [66]. The relationship observed in our own research confirms the increase in tenderness (decrease in cutting force) of meat as the amount of these products increases.

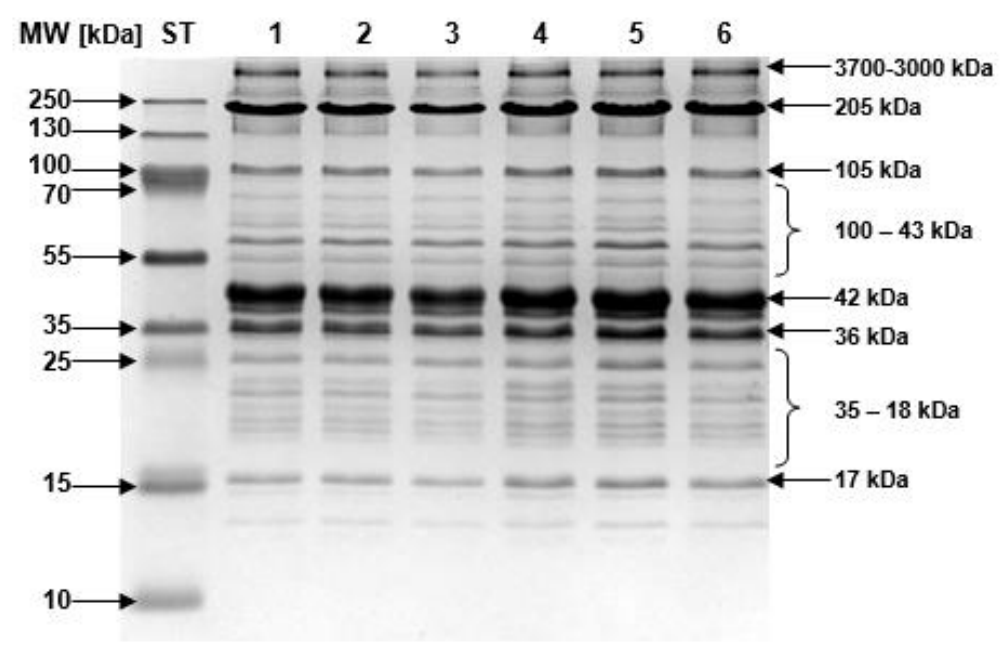

Figure 2. Comparison of distributions of muscle fiber protein types in longissimus lumborum: 1, 3, 5-control groups (C, E1, and E2, respectively); 2, 4, 6 experimental groups (C + EM, E1 + EM, and E2 + EM, respectively). 
This study also revealed a positive correlation $(\mathrm{r}=0.629 ; p<0.05)$ between the $205 \mathrm{kDa}$ band, which contained heavy MHC myosin chains, and the percentage of fat content. It should be emphasised that the composition of lipids is one of the main characteristics related to the quality of meat, and that it is influenced by the type of muscle fibers. However, unlike in our own research, these relationships between IMF intramuscular fat content and fatty acid composition and the presence of myosin isoforms in Cinta Senese pigs [67] were not demonstrated.

In addition, for fast twitch fibers in chickens, the proteins that make up the Z-line are more susceptible to early post-mortem proteolytic degradation than in slow twitch fibers $[63,68]$.

\section{Conclusions}

In conclusion, the quality of meat was satisfactory in all groups of pigs examined. The beneficial effect of adding effective microorganisms (EMs) was found in nutritional variant II, where less thermal leakage from meat was found. Additionally, a beneficial effect of the different diet on less thermal leakage and larger loin eye area in the E2 experimental group was demonstrated. The addition of a probiotic to pigs' diet resulted in thicker muscle fibers, which was particularly evident in the case of the E1 + EM group, where a significant increase in the diameter of fast twitch fibers was noted. In the same group of pigs, EMs led to less fiber fission, which is a common lesion in fast-growing animals. Additionally, in terms of proteins, the above nutritional variant appears to be the most appropriate because it resulted in the most favorable percentage of the individual proteins after EM supplementation in the LL muscle.

Author Contributions: Conceptualization: P.R., and J.B.; methodology: P.R., H.J., D.C.-S., A.C., B.M., and J.B.; formal analysis: H.J., D.C.-S., and J.B.; investigation: P.R., D.C.-S., B.M., A.C., and J.B.; resources: A.C., D.C.-S., B.M., and J.B.; data curation: P.R., H.J., D.C.-S., and J.B.; writing-original draft preparation: P.R. and J.B.; writing-review and editing: P.R., H.J., D.C.-S., and J.B.; visualization: H.J., D.C.-S., and J.B.; supervision: J.B. All authors have read and agreed to the published version of the manuscript.

Funding: This research received no external funding.

Conflicts of Interest: The authors declare no conflict of interest.

Ethics Approval: The use of animals was reviewed and approved by the local ethics committee for the animal experiments in Bydgoszcz (decision no. 24/2017).

\section{References}

1. Pisula, A.; Pospiech, E. Meat-The Basics of Science and Technology, 1st ed.; SGGW: Warsaw, Poland, 2011; pp. 15-21.

2. Baer, A.A.; Miller, M.J.; Dilger, A.C. Pathogens of Interest to the Pork Industry: A Review of Research on Interventions to Assure Food Safety. Compr. Rev. Food Sci. Food Saf. 2013, 12, 183-217. [CrossRef]

3. Jukna, Č.; Jukna, V.; Šimkus, A. The effect of probiotics and phytobiotics on meat properties and quality in pigs. Vet. Med. Zoot. 2005, 29, 80-84.

4. Suo, C.; Yin, Y.; Wang, X.; Lou, X.; Song, D.; Wang, X.; Gu, Q. Effects of Lactobacillus plantarum ZJ316 on pig growth and pork quality. BMC Vet. Res. 2012, 8, 89. [CrossRef] [PubMed]

5. Meng, Q.W.; Yan, L.; Ao, X.; Zhou, T.X.; Wang, J.P.; Lee, J.H.; Kim, I.H. Influence of probiotics in different energy and nutrient density diets on growth performance, nutrient digestibility, meat quality, and blood characteristics in growing-finishing pigs. J. Anim. Sci. 2010, 88, 3320-3326. [CrossRef]

6. Migdał, W.; Wojtysiak, D.; Paściak, P. The Histochemical Profile of Fatteners' Muscles Depending on the Type of Muscles, Gender and Breed of Fatteners, Their Body Weight, and Feeding. ZYWN Nauk. Technol. J. A 2005, 3, 157-168. (In Polish)

7. Bogucka, J.; Kapelański, W. Microstructure of longissimus lumborum muscle and meat quality of native Polish pig breeds: Złotnicka Spotted and Puławska. Ann. Anim. Sci. 2016, 16, 1199-1210. [CrossRef]

8. Liu, Y.; Kong, X.; Jiang, G.; Tan, B.; Deng, J.; Yang, X.; Li, F.; Xiong, X.; Yin, Y. Effects of dietary protein/energy ratio on growth performance, carcass trait, meat quality, and plasma metabolites in pigs of different genotypes. J. Anim. Sci. Biotechnol. 2015, 6, 36. [CrossRef] 
9. Zhang, C.; Luo, J.; Yu, B.; Zheng, P.; Huang, Z.; Mao, X.; He, J.; Yu, J.; Chen, J.; Chen, D. Dietary resveratrol supplementation improves meat quality of finishing pigs through changing muscle fiber characteristics and antioxidative status. Meat Sci. 2015, 102, 15-21. [CrossRef]

10. Liao, F.S.; Nyachoti, M. Using probiotics to improve swine gut health and nutrient utilization. Anim. Nutr. 2017, 3, 331-343. [CrossRef]

11. Giliński, Z.; Grzegorczyk, K. Probiotics as immunostimulators in veterinary and human medicine. Życie Wet. 2017, 92, 871-875. (In Polish)

12. Laskowsk, E.; Jarosz, Ł.; Grądzki, Z. Effect of Multi-Microbial Probiotic Formulation Bokashi on Pro- and Anti-Inflammatory Cytokines Profile in the Serum, Colostrum and Milk of Sows, and in a Culture of Polymorphonuclear Cells Isolated from Colostrum. Probiotics Antimicrob. Proteins 2019, 11, 220-232.

13. Jerzak, M.A.; Czerwińska-Kayzer, D.; Florek, J.; Śmiglak-Krajewska, M. Determinants for the Production of Legumes as an Alternative Source of Protein in the New Area of Agricultural Policy within Poland. Rocz. Nauk Rol. 2012, 99, 113-120. (In Polish)

14. Reszka, P.; Dunislawska, A.; Slawinska, A.; Siwek, M.; Kapelanski, W.; Bogucka, J. Influence of the effective microorganisms (em) on performance, intestinal morphology, and gene expression in the jejunal mucosa of pigs fed different diets. J. Anim Physiol An. 2020, 104, 1-10. [CrossRef] [PubMed]

15. Grau, R.; Hamm, R. Eine einfache Methode zur Bestimmung der Wasserbindung im Fleisch. Fleischwirtschaft 1952, 4, 295-297.

16. Pohja, M.S.; Niinivaara, F.P. Die Bestimmung der Wasserbindung des Fleisches mittels der Konstantdruckmethode. Fleischwirtschaft 1957, 9, 193-195.

17. Walczak, Z. Laboratory method for determining the content of jelly in canned meat. Rocz. Nauk Rol. 1959, 74, 619-626.

18. CIE. Colorimetry, Publication CIE 15.2, 2nd ed.; CIE: Vienna, Austria, 1986.

19. Cheng, W.; Cheng, J.H.; Sun, D.W.; Pu, H. Marbling Analysis for Evaluating Meat Quality: Methods and Techniques. Compr. Rev. Food Sci. Food Saf. 2015, 14, 523-535.

20. NPPC (National Pork Producers Council). NPPC Marbling Standards; NPPC: Des Moines, IA, USA, 1999.

21. Szalata, M.; Pospiech, E.; Łyczyński, A.; Urbaniak, M.; Frankiewicz, A.; Mikołajczak, B.; Medyński, A.; Rzosińska, E.; Bartkowiak, Z.; Danyluk, B. Tenderness of meat from pigs of various quality. Rocz. Inst. Przem. Mięsnego Ttuszcz. 1999, 36, 61-76.

22. Ziegan, J. Kombinationen enzymhistochemischer Methoden zur Fasertypendifferenzierung und Beurteilung der Skeletmuskulatur. Acta Histochem. 1979, 65, 34-40.

23. Dubovitz, W.; Brooke, M.; Neville, H.E. Muscle Biopsy: A Modern Approach; W. B. Saunders Company LTD London: Toronto, ON, Canada, 1973.

24. Brooke, M.H. Some comments on neural influence on the two histochemical types of muscle fibres. In Physiology and Biochemistry on Muscle as a Food; Briskey, E.J., Cassens, R.G., Marsh, B.B., Eds.; University of Wisconsin: Madison, WI, USA, 1970; p. 131.

25. Fritz, J.D.; Greaser, M.L. Changes in titin and nebulin in postmortem bovine muscle revealed by gel-electrophoresis, western blotting and immunofluorescence microscopy. J. Food Sci. 1991, 56, 607-610. [CrossRef]

26. Rybarczyk, A.; Romanwoski, M.; Karamucki, T.; Ligocki, M. The effect of Bokashi probiotic on pig carcass characteristics and meat quality. Fleischwirtsch. Int. 2016, 31, 74-77.

27. Yang, X.; Zhang, B.; Guo, Y.; Jiao, P.; Long, F. Effects of dietary lipids and Clostridium butyricum on fat deposition and meat quality of broiler chickens. Poult Sci. 2010, 89, 254-260. [PubMed]

28. Chang, S.Y.; Belal, A.A.; Kang, A.R.; Choi, Y.I.; Kim, Y.H.; Choe, H.S.; Heo, J.Y.; Shim, K.S. Influence of Probiotics-Friendly Pig Production on Meat Quality and Physicochemical Characteristics. Korean J. Food Sci. Anim. Resour. 2018, 38, 403-416. [CrossRef] [PubMed]

29. Dowarah, R.; Verma, A.K.; Agarwal, N.; Singh, P. Efficacy of species-specific probiotic Pediococcus acidilactici FT28 on blood biochemical profile, carcass traits and physicochemical properties of meat in fattening pigs. Res. Vet. Sci. 2018, 117, 60-64. [CrossRef]

30. Cebulska, A.; Václavková, E.; Bocian, M.; Dybała, J.; Wiśniewska, A.; Kapelański, W. Quality and dietary value of pork meat of the Puławska and Złotnicka Spotted breeds, and commercial fattening pigs. Ann. Anim. Sci. 2018, 18, 281-291. [CrossRef] 
31. Bogucka, J.; Kapelański, W. Microstructure of longissimus lumborum Muscle in Pigs of several Breeds and Its Relation to Meat Quality Traits. Folia Biol. 2005, 53, 85-90. [CrossRef]

32. Bocian, M.; Kapelański, W.; Adamowicz, M.; Jankowiak, H.; Cebulska, A.; Gimińska, A.; Mońko, A. Influence of nutrition of pigs with legume-enriched mixtures on the quality of pork. Nauka Przyr. Technol. 2016, 10, 46. [CrossRef]

33. Zmudzińska, A.; Bigorowski, B.; Banaszak, M.; Roślewska, A.; Adamski, M.; Hejdysz, M. The Effect of diet based on legume seeds and rapeseed meal on pig performance and meat quality. Animals 2020, 10, 1084.

34. Zaworska-Zakrzewska, A.; Kasprowicz-Potocka, M.; Wiśniewska, Z.; Rutkowski, A.; Hejdysz, M.; Kaczmarek, S.; Nowak, P.; Zmudzińska, A.; Banaszak, M. The chemical composition of domestic soybean seeds and the effects of partial substitution of soybean meal by raw soybean seeds in the diet on pigs' growth performance and pork quality (m. longissimus lumborum)*. Ann. Anim. Sci. 2020, 20, 521-533. [CrossRef]

35. Balasubramanian, B.; Lee, S.I.; Kim, I.H. Inclusion of dietary multi-species probiotic on growth performance, nutrient digestibility, meat quality traits, faecal microbiota and diarrhoea score in growing-finishing pigs. Ital. J. Anim. Sci. 2017, 17, 100-106. [CrossRef]

36. Bocian, M.; Jankowiak, H.; Kapelański, W.; Reszka, P.; Szafrańska, M. Results of pork meat quality assessment in relation to its tenderness. Post. Nauk. Technol. Przem. Rol. Spoż. 2017, 72, 5-14. (In Polish)

37. Liu, T.Y.; Su, B.C.; Wang, J.L.; Zhang, C.; Shan, A.S. Effects of probiotics on growth, pork quality and serum metabolites in growing-finishing pigs. J. Northeast Agric. Univ. 2013, 20, 57-63. [CrossRef]

38. Balasubramanian, B.; Li, T.; Kim, W.H. Effects of supplementing growing-finishing pig diets with Bacillus spp. probiotic on growth performance and meat-carcass grade quality traits. R. Bras. Zootec. 2016, 45, 93-100. [CrossRef]

39. Listrat, A.; Lebret, B.; Louveau, I.; Astruc, T.; Bonnet, M.; Lefaucheur, I.; Picard, B.; Bugeon, J. How Muscle Structure and Composition Influence Meat and Flesh Quality. Sci. World J. 2016, 16, 14. [CrossRef]

40. Lebedová, N.; Okrouhlá, M.; Zadinová, K.; Čitek, Z.; Stupka, R. Muscle fibre composition and meat quality in pigs with different nutrition level. In Proceedings of the IOP Conference Series: Materials Science and Engineering, 2nd Nommensen International Conference on Technology and Engineering, Medan, Indonesia, 19-20 July 2018.

41. Brzobohatý, L.; Stupka, R.; Čítek, J.; Šprysl, M.; Okrouhlá, M.; Vehovský, K.; Kluzáková, E. The effects of different nutrient composition in the feed on the muscle fibers typology in pigs. Res. Pig Breed. 2013, 7, 7-11.

42. Zhou, Y.; Ruan, Z.; Li, X.L.; Mi, S.M.; Jiang, M.; Liu, W.H.; Yang, H.S.; Wu, X.; Jiang, G.L.; Yin, Y.L. Eucommia ulmoides Oliver leaf polyphenol supplementation improves meat quality and regulates myofiber type in finishing pigs. J. Anim. Sci. 2016, 94, 164-168. [CrossRef]

43. Muqader, S. Single or Combined Effect of Zinc and Probiotics on Gut Morphology, Muscle and Hematological Parameters of Healthy and Heat Stressed Broiler Chicken. Ph.D. Thesis, University of Veterinary and Animal Sciences, Lahore, Pakistan, 2018.

44. Zhou, X.; Jin, E.; Li, S.; Wang, C.; Qiao, E.; Wu, G. Effects of dietary supplementation of probiotics (Bacillus subtilis, Bacillus licheniformis, and Bacillus natto) on broiler muscle development and meat quality. Turk. J. Vet. Anim. Sci. 2015, 39, 203-210. [CrossRef]

45. Jin, E.; Hu, Q.; Ren, M.; Jin, G.; Liang, L.; Li, S. Effects of Selenium Yeast in Combination with Boron on Muscle Growth and Muscle Quality in Broilers. Biol. Trace Elem. Res. 2019, 190, 472-483. [CrossRef]

46. Bogucka, J.; Poławska, E.; Elminowska-Wenda, G.; Raj, S.; Sobolewska, A.; Walasik, K.; Skiba, G.; Weremko, D.; Fandrejewski, H. Effect of nutritional regulation of growth on histochemical characteristics of muscles in pigs. Acta Agric. Scand. Sec. A 2013, 63, 10-17. [CrossRef]

47. Bogucka, J.; Ribeiro, D.M.; Costa, R.P.R.; Bednarczyk, M. Effect of synbiotic dietary supplementation on histological and histopathological parameters of Pectoralis major muscle of broiler chickens. Czech J. Anim. Sci. 2018, 63, 263-271. [CrossRef]

48. Skiba, G.; Raj, S.; Poławska, E.; Pastuszewska, B.; Elminowska- Wenda, G.; Bogucka, J.; Knecht, D. Profile of fatty acids, muscle structure and shear force of musculus longissimus dorsi (MLD) in growing pigs as affected by energy and protein or protein restriction followed by realimentation. Meat Sci. 2012, 91, 339-346. [CrossRef] [PubMed]

49. Brzobohaty, L.; Stupka, R.; Čitek, J.; Šprysl, M.; Okrouhlá, M.; Vehovský, K. The influence of controlled nutrition intensity on the muscle fiber characteristics in fattening pigs. J. Cent. Eur. Agric. 2015, 16, 92-99. [CrossRef] 
50. Fiedorowicz-Szatkowska, E.; Sobotka, W.; Stanek, M. Fattening performance and the nutritional value of meat from finishing pigs fed diets containing different sources of vegetable protein. J. Elem. 2017, 22, 1235-1242.

51. Madera, M.S.; Lopes, P.; Costa, P.J.; Coelho, D.R.; Alfaia, C.M.; Prates, J.A.M. Reduced protein diets increase intramuscular fat of psoas major, a red muscle, in lean and fatty pig genotypes. Animals 2017, 11, 2094-2102. [CrossRef] [PubMed]

52. Lopez, P.A.; Costa, A.S.H.; Costa, P.; Pires, V.M.R.; Madeira, M.S.; Achega, F.; Pinto, R.M.A.; Prates, J.A.M. Contrasting cellularity on fat deposition in the subcutaneous adipose tissue and longissimus lumborum muscle from lean and fat pigs under dietary protein reduction. Animals 2014, 8, 629-637. [CrossRef]

53. Olivares, A.; Daza, A.; Rey, A.I.; Lopez-Bote, C.J. Interactions between genotype, dietary fat saturation and vitamin A concentration on intramuscular fat content and fatty acid composition in pigs. Meat Sci. 2009, 82, 6-12. [CrossRef]

54. Wojtysiak, D. Pathological Changes in the Microstructure of longissimus lumborum Muscle from Five Breeds of Pigs. Folia Biol. 2012, 60, 55-60. [CrossRef]

55. Górska, M.; Wojtysiak, D. Pathological Changes in the Microstructure of Pale, Soft, Exudative (PSE) and Normal Turkey Breast Muscle. Folia Biol. 2017, 65, 148-153. [CrossRef]

56. Bogucka, J.; Elminowska-Wenda, G.; Walasik, K.; Kapelański, W. Incidence of histopathological changes in longissimus lumborum muscle of wild boar-domestic pig hybrids. Pol. J. Food Nutr. Sci. 2007, 57, 49-52.

57. Makovický, P.; Makovický, P. Histological Aspects of Skeletal Muscle Fibers Splitting of C57BL/6NCrl Mice. Physiol. Res. 2020, 69, 291-296. [CrossRef]

58. Semenova, A.A.; Kuznetsova, T.G.; Nasonova, V.V.; Nekrasov, R.V.; Bogolyubova, N.V. Myopathy as a destabilizing factor of meat quality formation. Theory Pr. Meat Proc. 2019, 4, 24-31. [CrossRef]

59. Malva, A.; Marino, R.; Santillo, A.; Annicchiarico, G.; Caroprese, M.; Sevi, A.; Albenzio, M. Proteomic approach to investigate the impact of different dietary suplementation on lamb meat tenderness. Meat Sci. 2017, 131, 74-81. [CrossRef] [PubMed]

60. Adeyemi, K.D.; Sabow, A.B.; Shittu, R.M.; Karim, R.; Sazili, A. Influence of dietary canola oil and palm oil blend and refrigerated storage on fatty acids, myofibrillar proteins, chemical composition, antioxidant profile and quality attributes of semimembranosus muscle in goats. J. Anim. Sci. Biotechnol. 2015, 6, 51. [CrossRef] [PubMed]

61. Huff-Lonergan, E.; Zhang, W.G.; Lonergan, S.M. Biochemistry of postmortem muscle- lessons on mechanisms of meat tenderization. Meat Sci. 2010, 86, 184-195. [CrossRef]

62. Zhang, W.G.; Xiao, S.; Ahn, D.U. Protein oxidation: Basic principles and implications for meat quality. Crit. Rev. Food Sci. Nutr. 2013, 53, 1191-1201. [CrossRef]

63. Lee, S.H.; Joo, S.T.; Ryu, Y.C. Skeletal muscle fiber type and myofibrillar proteins in relation to meat quality. Meat Sci. 2010, 86, 166-170. [CrossRef]

64. Marino, R.; Albenzio, M.; della Malva, A.; Caroprese, M.; Santillo, A. Changes in meat quality traits and sarcoplasmic proteins during aging inthree different cattle breeds. Meat Sci. 2014, 54, 187-196.

65. Grześ, B.; Pospiech, E.; Iwańska, E.; Mikołajczak, B.; Łyczyński, A.; Koćwin-Podsiadła, M.; Krzęcio-Niczyporuk, E. The relationship between protein changes in porcine longissimus muscle at different courses of meat tenderisation. Eur. Food Res. Technol. 2017, 243, 2025-2034. [CrossRef]

66. Iwańska, E.; Mikołajczak, B.; Grześ, B.; Pospiech, E. Impact of post mortem aging of pork on changes in the isoelectric point of the proteins and tenderness. Med. Weter 2016, 72, 458-462. (In Polish)

67. Velotto, S.; Ashkezary, M.R.; de Camillis, D.; Todaro, A. Myosin heavy chain isoforms, fatty acid composition, sensory evaluation and quality of cinta senese pig meat. Ital. J. Food Sci. 2018, 30, 650-661.

68. Choi, Y.M.; Kim, B.C. Muscle fiber characteristics, myofibrillar protein isoforms, and meat quality. Livest. Sci. 2009, 122, 105-118. [CrossRef]

(C) 2020 by the authors. Licensee MDPI, Basel, Switzerland. This article is an open access article distributed under the terms and conditions of the Creative Commons Attribution (CC BY) license (http://creativecommons.org/licenses/by/4.0/). 